\title{
Supplemental Smartamine M or MetaSmart during the transition period benefits postpartal cow performance and blood neutrophil function
}

\author{
J. S. Osorio, ${ }^{\star} \dagger$ P. Ji, ${ }^{*} \dagger^{1}$ J. K. Drackley, $\dagger$ D. Luchini, $\ddagger$ and J. J. Loor ${ }^{*}{ }^{2}$ \\ *Mammalian NutriPhysioGenomics, and \\ †Department of Animal Sciences and Division of Nutritional Sciences, University of Illinois, 1207 West Gregory Drive, Urbana 61801 \\ $\ddagger$ Adisseo, Alpharetta, GA 30022
}

\begin{abstract}
The onset of lactation in dairy cows is characterized by severe negative energy and protein balance. Methionine availability during this time for milk production, hepatic lipid metabolism, and immune function may be limiting. Supplementing Met to peripartal diets with adequate Lys in metabolizable protein (MP) to fine-tune the Lys:Met ratio may be beneficial. Fifty-six multiparous Holstein cows were fed the same basal diet from $50 \mathrm{~d}$ before expected calving to $30 \mathrm{~d}$ in milk. From -50 to $-21 \mathrm{~d}$ before expected calving, all cows received the same diet $[1.24 \mathrm{Mcal} / \mathrm{kg}$ of dry matter (DM), $10.3 \%$ rumen-degradable protein, and $4 \%$ rumen-undegradable protein] with no Met supplementation. From -21 $\mathrm{d}$ to expected calving, the cows received diets (1.54 $\mathrm{Mcal} / \mathrm{kg}$ of DM, $10 \%$ rumen-degradable protein, and $5.1 \%$ rumen-undegradable protein) with no added Met (control, CON; $\mathrm{n}=14$ ), CON plus MetaSmart (MS; Adisseo Inc., Antony, France; $\mathrm{n}=12$ ), or CON plus Smartamine M (SM; Adisseo Inc.; n = 12). From calving through $30 \mathrm{~d}$ in milk, the cows received the same postpartum diet $(1.75 \mathrm{Mcal} / \mathrm{kg}$ of DM and $17.5 \% \mathrm{CP}$; CON), or the CON plus MS or CON plus SM. The Met supplements were adjusted daily and top-dressed over the total mixed ration at a rate of 0.19 or $0.07 \%$ (DM) of feed for MS or SM. Liver tissue was collected on $-10,7$, and $21 \mathrm{~d}$, and blood samples more frequently, from -21 through $21 \mathrm{~d}$. Data were analyzed using the MIXED procedure of SAS (SAS Institute Inc., Cary, $\mathrm{NC}$ ) with the preplanned contrasts $\mathrm{CON}$ versus $\mathrm{SM}+$ MS and SM versus MS. No differences in prepartal DM intake (DMI) or body condition score were observed. After calving, body condition score was lower (2.6 vs. 2.8 ), whereas DMI was greater (15.4 vs. $13.3 \mathrm{~kg} / \mathrm{d}$ ) for Met-supplemented cows. Postpartal diet $\times$ time interactions were observed for milk fat percentage, milk
\end{abstract}

\footnotetext{
Received May 31, 2012.

Accepted June 10, 2013.

${ }^{1}$ Current address: Miner Research Institute, 1034 Miner Farm Road, PO Box 100, Chazy, NY 12921.

${ }^{2}$ Corresponding author: jloor@illinois.edu
}

fat yield, energy-corrected milk:DMI ratio, and energy balance. These were mainly due to changes among time points across all treatments. Cows supplemented with either Met source increased milk yield, milk protein percentage, energy-corrected milk, and milk fat yield by $3.4 \mathrm{~kg} / \mathrm{d}, 0.18 \%$ units, $3.9 \mathrm{~kg} / \mathrm{d}$, and $0.18 \mathrm{~kg} / \mathrm{d}$, respectively. Those responses were associated with greater postpartum concentration of growth hormone but not insulin-like growth factor 1 . There was a diet $\times$ time effect for nonesterified fatty acid concentration due to greater values on d 7 for MS; however, liver concentration of triacylglycerol was not affected by diet or diet $\times$ time but increased postpartum. Blood neutrophil phagocytosis at $21 \mathrm{~d}$ was greater with Met supplementation, suggesting better immune function. Supplemental MS or SM resulted in a tendency for lower incidence of ketosis postpartum. Although supplemental MS or SM did not decrease liver triacylglycerol, it improved milk production-related traits by enhancing voluntary DMI. Key words: methionine, transition cow, inflammation

\section{INTRODUCTION}

Nutritional requirements of dry cows increase as gestation progresses because of fetal growth, which is exponential in late gestation (NRC, 2001). Conditions such as increased blood glucocorticoids, lipid mobilization, and fetal size contribute to reducing voluntary DMI. In turn, nutrient availability for the cow and fetus decreases (Ingvartsen and Andersen, 2000). Clearly, the amount of MP flowing to the intestine from both dietary and microbial sources can be diminished by lower DMI around calving.

Limited research suggests that RUP is ca. $50 \%$ of the total MP and that increasing RUP during late gestation improves subsequent lactation performance (Huyler et al., 1999; Greenfield et al., 2000). The RUP is important as a source of essential AA (EAA; e.g., Met) for body tissues, which are the building blocks of enzymes and hormones of importance in a number of biological functions. Therefore, it might be expected that an adequate profile of EAA in RUP is crucial for a successful transition for both the cow and the unborn 
calf. Research has determined that Met and Lys in MP are the most-limiting AA in a wide range of diets for dairy cows (NRC, 2001). In fact, Met is typically first limiting and supplementation of Met alone improved overall lactation performance in dairy cows (Armentano et al., 1997; Rulquin and Delaby, 1997).

Among the various biological functions besides milk protein synthesis for which Met availability is important, some of the most relevant to the peripartal period include its role in liver lipoprotein synthesis, as substrate for antioxidant reactions, and the immune function (Durand et al., 1992; Soder and Holden, 1999; Chen et al., 2007). Perhaps the most important metabolic role of Met at the level of the liver is as a lipotropic agent that can stimulate the synthesis of very low density lipoproteins (VLDL), and consequently help minimize the accumulation of triacylglycerol (TAG; Bauchart et al., 1998; Martinov et al., 2010). Oxidative stress status also could be influenced by Met availability because it could serve as a substrate for glutathione synthesis via homocysteine produced in the Met cycle (Martinov et al., 2010). Glutathione is one of the most abundant natural antioxidants produced within the liver, and a reduction in its synthesis in rodents leads to steatosis, mitochondrial damage, and marked increases in lipid peroxidation (Chen et al., 2007).

There is still a limited amount of data on the efficacy of supplementing Met during the peripartal period (i.e., the last 3 wk through the first 3 wk relative to parturition; Phillips et al., 2003; Socha et al., 2005; Johnson-VanWieringen et al., 2007), and specifically for the isopropyl ester of 2-hydroxy-4-(methylthio)butanoic acid [HMBi; MetaSmart (MS); Adisseo Inc., Antony, France; Ordway et al., 2009]. A common objective of previous experiments (Armentano et al., 1997; Rulquin and Delaby, 1997) has been to achieve optimal or near-optimal level of Lys in MP to maintain a 3:1 ratio of Lys to Met as estimated by NRC (2001), especially after calving. These previous studies have not reported incidences of clinical disease; thus, it is difficult to ascertain what affects MS or SM might have in that regard.

Based on previous research in lactating dairy cows (Rulquin et al., 2006; Chen et al., 2011) or peripartal cows (Ordway et al., 2009; Socha et al., 2005), we hypothesized that either Smartamine M (SM; Adisseo Inc.) or MS would improve DMI, milk yield, and milk protein concentration. Because ca. $50 \%$ of $\mathrm{HMBi}$ in MS is hydrolyzed into 2-hydroxy-4-(methylthio)-butanoic acid and further degraded by rumen microorganisms (Robert et al., 2001), we also hypothesized a greater response in milk fat for cows fed MS. Additionally, L-Met supplementation has been previously associated with an improvement in hepatic lipid metabolism in calves
(Auboiron et al., 1994; Auboiron et al., 1995) and dairy cows (Durand et al., 1992); thus, it is conceivable that inclusion of SM or MS during the peripartal period might alleviate overload of FA in the liver and consequently decrease the incidence of fatty liver and ketosis. The objective of this experiment was to evaluate the effects of supplementing during the peripartal period (-21 through 30 DIM) SM or MS in amounts that would result in a predicted 2.9:1 ratio of Lys to Met.

\section{MATERIALS AND METHODS}

\section{Experimental Design and Dietary Treatments}

The Institutional Animal Care and Use Committee (IACUC) of the University of Illinois (Urbana) approved all procedures for this study (protocol no. 09214). The experiment was conducted as a randomized complete block design where 45 multiparous Holstein cows were blocked according to parity, previous lactation milk yield, and expected day of calving. Eleven multiparous Holstein cows were later included for cows that had to be removed unexpectedly from the experiment. Thus, a total of 56 multiparous Holstein cows were fed experimental treatments consisting of a basal control (CON) $\operatorname{diet}(\mathrm{n}=24)$ with no Met supplementation, CON plus MS $(n=15)$ at a rate of $0.19 \%$ of $\mathrm{DM}$, or CON plus $\mathrm{SM}(\mathrm{n}=18)$ at a rate of $0.07 \%$ of DM. After calving, a total of 17 cows were removed from the experiment based on clinical disease (per IACUC guidelines) or twinning. This translated into removal of 10,3 , and 4 in CON, MS, and SM groups, respectively (Table 1). Therefore, the numbers of cows in Table 1 reflect the fact that more cows had to be allocated to the CON diet in an attempt to balance the replicates among the treatments. The complete data set from 14, 12, and, 13 cows in the CON, MS, and SM group, respectively, was used for statistical analysis. All cows received the same far-off diet (1.24 Mcal $/ \mathrm{kg}$ of DM, $10.3 \% \mathrm{RDP}$, and $4 \%$ RUP) from -50 to $-21 \mathrm{~d}$ before expected calving, close-up diet (1.54 Mcal/kg of DM, $10 \%$ RDP, and $5.1 \%$ RUP) from $-21 \mathrm{~d}$ to expected calving, and lactation diet from calving (1.75 Mcal/kg DM, $10.9 \%$ RDP, and $6.5 \%$ RUP) through 30 DIM (Table 2). Methionine supplements were top-dressed from -21 to 30 DIM.

MetaSmart was supplied as a dry powder consisting of $57 \% \mathrm{HMBi}$, which in turn, is $78 \%$ Met equivalent, of which $50 \%$ is absorbed through the rumen wall (Graulet et al., 2005); therefore, for each $10 \mathrm{~g}$ of MS, the cow received $2.22 \mathrm{~g}$ of Met. In contrast, SM contains $75 \%$ DL-Met, physically protected by a pH-sensitive coating, which is considered to have a Met bioavailability of $80 \%$ (Schwab, 2007); therefore, per $10 \mathrm{~g}$ of $\mathrm{SM}$, the cows received $6 \mathrm{~g}$ of metabolizable Met. Using 
Table 1. Frequency of occurrence of health problems and twinning in cows supplemented with MetaSmart (MS; Adisseo Inc., Antony, France) or Smartamine M (SM; Adisseo Inc.) during the peripartal period

\begin{tabular}{|c|c|c|c|c|c|c|}
\hline \multirow[b]{2}{*}{ Variable } & \multicolumn{3}{|c|}{ Diet $^{1}$} & \multicolumn{3}{|c|}{$P$-value } \\
\hline & $\mathrm{CON}$ & MS & SM & Diet & & Met \\
\hline $\mathrm{n}$ & 24 & 15 & 17 & - & & - \\
\hline Twins & 2 & 0 & 1 & 0.78 & 0.57 & \\
\hline Ketosis $^{2}$ & 6 & 1 & 2 & 0.34 & 0.15 & \\
\hline Displaced abomasum & 3 & 2 & 2 & 1.00 & 1.00 & \\
\hline Retained placenta $^{3}$ & 0 & 1 & 1 & 0.32 & 0.50 & \\
\hline Excluded cows $^{4}$ & 10 & 3 & 4 & - & & - \\
\hline
\end{tabular}

${ }^{1} \mathrm{CON}=$ control; $\mathrm{MS}=\mathrm{CON}+\mathrm{MS}(0.19 \%$ of DMI $) ; \mathrm{SM}=\mathrm{CON}+\mathrm{SM}(0.07 \%$ of DMI$)$.

${ }^{2}$ Defined as cows having moderate $(\sim 40 \mathrm{mg} / \mathrm{dL})$ or large ketone concentrations $(>80 \mathrm{mg} / \mathrm{dL})$ in urine, as detected using a reagent strip and treated by veterinarians with oral propylene glycol or intravenous dextrose. ${ }^{3}$ Defined as fetal membranes retained $>24 \mathrm{~h}$ postpartum.

${ }^{4}$ Actual number of cows excluded from the experiment, where 4 cows were diagnosed with 2 clinical diseases after calving.

Table 2. Ingredient composition of diets fed during far-off ( -50 to $-21 \mathrm{~d}$ relative to expected calving), closeup ( $-21 \mathrm{~d}$ to calving), and early lactation periods ${ }^{1}$

\begin{tabular}{|c|c|c|c|}
\hline \multirow[b]{2}{*}{ Ingredient ( $\%$ of DM) } & \multicolumn{3}{|c|}{ Diet $^{1}$} \\
\hline & Far-off & Close-up & Lactation \\
\hline Alfalfa silage & 12.00 & 8.20 & 5.00 \\
\hline Alfalfa hay & - & 3.50 & 4.00 \\
\hline Corn silage & 33.00 & 35.90 & 33.00 \\
\hline Wheat straw & 36.00 & 15.40 & 4.00 \\
\hline Cottonseed & — & - & 3.50 \\
\hline Wet brewers grains & - & 6.00 & 10.00 \\
\hline Ground shelled corn & 4.00 & 13.00 & 22.20 \\
\hline Soy hulls & 2.00 & 4.00 & 4.00 \\
\hline Soybean meal, $48 \%$ CP & 7.92 & 3.10 & 3.30 \\
\hline Expeller soybean meal $^{2}$ & - & 2.00 & 6.20 \\
\hline SoyChlor ${ }^{3}$ & 0.15 & 3.80 & - \\
\hline Blood meal, $85 \%$ CP & 1.00 & 1.00 & 0.30 \\
\hline Urea & 0.45 & 0.30 & 0.14 \\
\hline Rumen-inert fat ${ }^{4}$ & - & - & 1.00 \\
\hline Limestone & 1.30 & 1.30 & 1.18 \\
\hline Salt (plain) & 0.32 & 0.30 & 0.27 \\
\hline Dicalcium phosphate & 0.12 & 0.18 & 0.27 \\
\hline Magnesium oxide & 0.21 & 0.08 & 0.14 \\
\hline Magnesium sulfate & 0.91 & 0.97 & - \\
\hline Sodium bicarbonate & - & - & 0.75 \\
\hline Potassium carbonate & - & - & 0.10 \\
\hline Calcium sulfate & - & - & 0.10 \\
\hline Mineral-vitamin $\operatorname{mix}^{5}$ & 0.20 & 0.20 & 0.20 \\
\hline Vitamin $A^{6}$ & 0.015 & 0.015 & - \\
\hline Vitamin $\mathrm{D}^{7}$ & 0.025 & 0.025 & - \\
\hline Vitamin $E^{8}$ & 0.38 & 0.38 & - \\
\hline Biotin & - & 0.35 & 0.35 \\
\hline
\end{tabular}

${ }^{1}$ Basal close-up and lactation diets were considered as $\mathrm{CON}=$ control, $\mathrm{MS}=$ MetaSmart [Adisseo Inc., Antony, France; CON + MS (0.19\% of DMI)], and SM = Smartamine M [Adisseo Inc.; CON + SM (0.07\% of DMI)].

${ }^{2}$ SoyPLUS (West Central Soy, Ralston, IA).

${ }^{3}$ By West Central Soy.

${ }^{4}$ Energy Booster 100 (MSC, Carpentersville, IL).

${ }^{5}$ Contained a minimum of $5 \% \mathrm{Mg}, 10 \% \mathrm{~S}, 7.5 \% \mathrm{~K}, 2.0 \% \mathrm{Fe}, 3.0 \% \mathrm{Zn}, 3.0 \% \mathrm{Mn}, 5,000 \mathrm{mg}$ of Cu/kg, $250 \mathrm{mg}$ of $\mathrm{I} / \mathrm{kg}, 40 \mathrm{mg}$ of $\mathrm{Co} / \mathrm{kg}, 150 \mathrm{mg}$ of Se/ $\mathrm{kg}, 2,200 \mathrm{kIU}$ of vitamin $\mathrm{A} / \mathrm{kg}, 660 \mathrm{kIU}$ of vitamin $\mathrm{D}_{3} / \mathrm{kg}$, and 7,700 IU of vitamin $\mathrm{E} / \mathrm{kg}$.

${ }^{6}$ Contained 30,000 kIU $/ \mathrm{kg}$.

${ }^{7}$ Contained $5,009 \mathrm{kIU} / \mathrm{kg}$.

${ }^{8}$ Contained 44,000 IU $/ \mathrm{kg}$. 
Table 3. Nutrient composition and evaluation (NRC, 2001) of prepartal and postpartal diets fed to cows supplemented with MetaSmart (MS; Adisseo Inc., Antony, France) or Smartamine M (SM; Adisseo Inc.) during the peripartal period ${ }^{1}$

\begin{tabular}{|c|c|c|c|c|c|c|c|}
\hline \multirow{2}{*}{ Chemical component $^{2}$} & \multicolumn{4}{|c|}{ Prepartum } & & & \\
\hline & Far-off & \multicolumn{3}{|c|}{ Close-up } & \multicolumn{3}{|c|}{ Postpartum } \\
\hline $\mathrm{NE}_{\mathrm{L}}(\mathrm{Mcal} / \mathrm{kg}$ of $\mathrm{DM})$ & 1.24 & 1.54 & 1.53 & 1.54 & 1.76 & 1.74 & 1.73 \\
\hline $\mathrm{CP}(\%$ of $\mathrm{DM})$ & 14.30 & 15.0 & 15.1 & 15.1 & 17.4 & 17.5 & 17.4 \\
\hline RDP (\% of DM) & 10.3 & 10 & 10 & 10 & 10.9 & 10.7 & 10.6 \\
\hline $\operatorname{ADF}(\%$ of $\mathrm{DM})$ & 35.5 & 28.4 & 28.3 & 28.4 & 22.6 & 22.6 & 22.6 \\
\hline RDP supplied (g/d) & 1,277 & 1,217 & 1,265 & 1,235 & 1,453 & 1,631 & 1,655 \\
\hline RDP balance $(\mathrm{g} / \mathrm{d})$ & 153 & 32 & 35 & 40 & 35 & 30 & 16 \\
\hline RUP supplied (g/d) & 499 & 618 & 654 & 631 & 859 & 1,022 & 1,062 \\
\hline RUP required (g/d) & 138 & 119 & 103 & 114 & 1,535 & 1,745 & 1,790 \\
\hline RUP balance (g/d) & 361 & 499 & 551 & 518 & -676 & -723 & -728 \\
\hline MP supplied (g/d) & 1,059 & 1,191 & 1,248 & 1,209 & 1,563 & 1,812 & 1,869 \\
\hline MP-Met (g) & 20 & 22 & 29 & 29 & 28 & 39 & 40 \\
\hline
\end{tabular}

${ }^{1}$ The NRC (2001) evaluation of diets was based on final DMI and production data and feed analysis.

${ }^{2}$ Composition of MS and SM supplied by Adisseo Inc. (Antony, France, and Alpharetta, GA).

${ }^{3} \mathrm{CON}=$ control.

these Met estimates for MS and SM, the quantity of product to be top-dressed for the respective diets was calculated to result in predicted concentrations of 6.19 and $2.12 \%$ of MP for Lys and Met, respectively, for the MS and SM diets according to NRC (2001; Table 3). Additionally, TMR DM for the close-up and lactation diets was measured weekly in order to estimate daily TMR DM offered. In turn, the amounts of MS $(0.19 \%)$ and SM $(0.07 \%)$ needed to reach our target level of Met supplementation were calculated using the data of TMR offered on a DM basis.

\section{Animal Management}

All cows were enrolled in the experiment from mid October 2009 to early July 2010, with an average temperature of $9.6 \pm 10.5{ }^{\circ} \mathrm{C}$ (Illinois State Water Survey; http://www.isws.illinois.edu/atmos/statecli/cuweather /index.htm). Cows were fed individually once daily at $0630 \mathrm{~h}$ using an individual gate system (American Calan Inc., Northwood, NH). Cows were housed in a ventilated enclosed barn during the dry period and had access to sand-bedded freestalls until $3 \mathrm{~d}$ before expected parturition, when they were moved to individual maternity pens bedded with straw until parturition. After parturition, cows were housed in a tie-stall barn and were fed a common lactation diet once daily (Table 2 ) and milked 3 times daily. At 30 DIM, cows returned to the farm herd. Feed offered was adjusted daily to achieve 5 to $10 \%$ refusals.

Body weight was measured weekly before the midday milking for each cow at the same time after the morning feeding. A BCS (scale $1=$ thin to $5=$ obese, with quarter-point increments) was assigned to each cow weekly by 2 individuals and the average score was used for statistical analysis. Intake of DM was recorded daily. Milk yield was recorded daily during the first 30 DIM. Also, milk composition was analyzed while ECM and EB were calculated from calving to 30 DIM.

\section{Feed and Milk Samples}

Dry matter of individual feed ingredients was determined weekly and rations were adjusted accordingly to maintain DM ratios of ingredients in the TMR. Weekly samples of ingredients and TMR were frozen at $-20^{\circ} \mathrm{C}$ and composited monthly for analysis of DM, CP, NDF, $\mathrm{ADF}, \mathrm{Ca}, \mathrm{P}, \mathrm{K}$, and $\mathrm{Mg}$ by standard wet chemistry techniques at a commercial laboratory (Dairy One, Ithaca, NY). Consecutive morning, midday, and evening milk samples were taken weekly until 30 DIM. Composite milk samples were prepared in proportion to milk yield at each milking, preserved (800 Broad Spectrum Microtabs II; D \& F Control Systems Inc., San Ramon, $\mathrm{CA}$ ), and analyzed for contents of fat, protein, lactose, SNF, MUN, and SCC (Dairy Lab Services, Dubuque, 
IA). Based on milk sample analysis, the ECM (at 3.5\% fat) was calculated daily as follows: $\mathrm{ECM}=[12.82 \times$ fat yield $(\mathrm{kg})]+[7.13 \times$ protein yield $(\mathrm{kg})]+[0.323 \times$ milk yield (kg)] (Hutjens, 2010).

Energy balance (EB) was calculated for each cow using equations from NRC (2001). Net energy intake $\left(\mathbf{N E}_{\mathbf{I}}\right)$ was determined using daily DMI multiplied by $\mathrm{NE}_{\mathrm{L}}$ density of the diet. Net energy of maintenance $\left(\mathrm{NE}_{\mathrm{M}}\right)$ was calculated as $\mathrm{BW}^{0.75} \times 0.080$. Requirements of $\mathrm{NE}_{\mathrm{L}}$ were calculated as $\mathrm{NE}_{\mathrm{L}}=(0.0929 \times$ fat $\%+$ $0.0547 \times$ protein $\%+0.0395 \times$ lactose $\%) \times$ milk yield. The net energy requirement for pregnancy $\left(\mathbf{N E}_{\mathbf{P}}\right.$; $\mathrm{Mcal} / \mathrm{d})$ was calculated as $\mathrm{NE}_{\mathrm{P}}=[(0.00318 \times$ day of gestation -0.0352$) \times($ calf birth weight/45)]/0.218 The equation used to calculate prepartal EB $\left(\mathbf{E B}_{\mathbf{P R E}}\right.$; Mcal/d) was $\mathrm{EB}_{\mathrm{PRE}}=\mathrm{NE}_{\mathrm{I}}-\left(\mathrm{NE}_{\mathrm{M}}+\mathrm{NE}_{\mathrm{P}}\right)$ and $\mathrm{EB}_{\mathrm{PRE}}$ $($ as $\%$ of requirements $)=\left[\mathrm{NE}_{\mathrm{I}} /\left(\mathrm{NE}_{\mathrm{M}}+\mathrm{NE}_{\mathrm{P}}\right)\right] \times 100$. The equation used to calculate postpartal EB (EBpost) was $\mathrm{EB}_{\text {POST }}(\mathrm{Mcal} / \mathrm{d})=\mathrm{NE}_{\mathrm{I}}-\left(\mathrm{NE}_{\mathrm{M}}+\mathrm{NE}_{\mathrm{L}}\right)$ and $\mathrm{EB}_{\text {POST }}$ (as \% of requirements) $=\left[\mathrm{NE}_{\mathrm{I}} /\left(\mathrm{NE}_{\mathrm{M}}+\right.\right.$ $\left.\left.\mathrm{NE}_{\mathrm{L}}\right)\right] \times 100$.

\section{Blood Collection and Analyses}

Blood was sampled from the coccygeal vein every Monday and Thursday before the morning feeding from -25 to 30 d. Samples were collected into evacuated serum tubes (BD Vacutainer; BD and Co., Franklin Lakes, NJ) containing either clot activator or lithium heparin for serum and plasma, respectively. After blood collection, tubes with lithium heparin were placed on ice and tubes with clot activator were kept at $21^{\circ} \mathrm{C}$ until centrifugation ( $\sim 30 \mathrm{~min})$. Serum and plasma were obtained by centrifugation at $1,900 \times g$ for 15 min at $4^{\circ} \mathrm{C}$. Aliquots of serum and plasma were frozen $(-20$ ${ }^{\circ} \mathrm{C}$ ) until further analysis. Measurements of NEFA and BHBA were performed using commercial kits in an autoanalyzer at the University of Illinois Veterinary Diagnostic Laboratory (Urbana). Glucose and TAG concentrations were measured using a commercial kit (LabAssay Triglyceride; Wako Chemicals Inc., Richmond, VA). Insulin concentration was quantified using a commercial bovine insulin ELISA kit (catalog no. 101201-01; Mercodia AB, Uppsala, Sweden). The concentration of VLDL was determined using a high-density lipoprotein and low-density lipoprotein (LDL)/VLDL cholesterol quantification kit (catalog no. K613-100; BioVision Inc., Mountain View, CA). Apolipoprotein B-100 (ApoB-100) was measured using a commercial kit (Bovine Apolipoprotein B100 ELISA kit; ABO Switzerland Co. Ltd., Xiamen, Fujian China). Quantification of growth hormone (GH), IGF1, and leptin concentration was as described by Graugnard et al. (2013).

\section{Liver Tissue Composition}

Liver was sampled via puncture biopsy (Dann et al., 2006) from cows under local anesthesia at approximate $0800 \mathrm{~h}$ on $\mathrm{d}-10,7$, and 21 relative to parturition. Liver was frozen immediately in liquid nitrogen and stored until further analysis for concentration of total lipid and TAG.

\section{Whole-Blood Phagocytosis}

The phagocytic capacity of PMNL isolated from heparinized whole blood was determined at $21 \mathrm{~d}$ postpartum using the Phagotest kit (Orpegen Pharma GmbH, Heidelberg, Germany; Ballou, 2012) following the manufacturer's instructions. In brief, $20 \mu \mathrm{L}$ of bacteria Escherichia coli was added to 1 of 3 wholeblood samples $(100 \mu \mathrm{L})$ in test tubes (Falcon; Becton Dickinson, Franklin Lakes, NJ) and incubated for 10 min at $37^{\circ} \mathrm{C}$. The cells were resuspended in $200 \mu \mathrm{L}$ of DNA-staining solution, and light-protected in an ice bath until analyzed by flow cytometry (LSR II; Becton Dickinson, San Jose, CA).

\section{Statistical Analysis}

Data were analyzed using PROC MIXED of SAS (SAS Institute Inc., Cary, NC) with the preplanned contrasts CON versus SM + MS and SM versus MS according to the following model:

$$
\begin{gathered}
Y_{i j k l m}=\mu+D_{i}+P_{j}+D P_{i j}+B_{k}+C_{i j k l} \\
+T_{m}+D T_{i m}+D P T_{i j m}+e_{i j k l m},
\end{gathered}
$$

where $Y_{i j k l m}$ is the dependent, continuous variable; $\mu$ is the overall mean; $D_{i}$ is the fixed effect of the $i$ th $\operatorname{diet}(i$ $=1,2$, or 3$) ; P_{j}$ is the fixed effect of the $j$ th parity $(j=$ $1,2$, or 3$) ; D P i j$ is the fixed effect of the $i$ th treatment by the $j$ th parity of the experiment interaction; $B_{k}$ is the random effect of the $k$ th block $(k=1, \ldots, 15)$; $C_{i j k l}$ is the random effect of the $l$ th cow within the $i$ th treatment, within the $j$ th parity, and within the $k$ th block $\left(l=1, \ldots, n_{i j k}\right) ; T_{m}$ is the fixed effect of the $m$ th time (day or week) of the experiment $(\mathrm{m}=1, \ldots$, $n) ; D T_{i m}$ is the fixed effect of the $i$ th treatment by the $m$ th time of the experiment interaction; $D P T_{i j m}$ is the fixed effect of the $i$ th treatment by the $j$ th parity by the $m$ th time of the experiment interaction; and $e_{i j k l m}$ is the residual error. Blood metabolites, insulin, and liver composition were analyzed at various time points that were not equally spaced. Therefore, an exponential correlation covariance structure SP (POW) was used for repeated measures. The covariate of previous 305-d milk yield was maintained in the model for all vari- 
Table 4. Effects of supplementing cows with MetaSmart (MS; Adisseo Inc., Antony, France) or Smartamine M (SM; Adisseo Inc.) during the peripartal period on DMI, BW, and BCS

\begin{tabular}{|c|c|c|c|c|c|c|c|c|c|}
\hline Parameter & \multicolumn{3}{|c|}{$\operatorname{Diet}^{1}$} & $\mathrm{SEM}^{2}$ & \multicolumn{5}{|c|}{$P$-value } \\
\hline \multicolumn{10}{|l|}{ Prepartum $^{6}$} \\
\hline BW (kg) & 773.7 & 762.8 & 766.2 & 4.8 & 0.26 & 0.12 & - & $<0.001$ & 0.14 \\
\hline $\mathrm{BCS}$ & 3.18 & 3.17 & 3.16 & 0.04 & 0.90 & 0.72 & 0.04 & $<0.001$ & 0.009 \\
\hline DMI (kg/d) & 12.2 & 12.7 & 12.3 & 0.48 & 0.67 & 0.49 & 0.05 & $<0.001$ & 0.42 \\
\hline DMI $(\%$ of $\mathrm{BW})$ & 1.54 & 1.68 & 1.60 & 0.07 & 0.35 & 0.23 & 0.003 & $<0.001$ & 0.70 \\
\hline BW (kg) & 670.8 & 660.3 & 645.3 & 20.5 & 0.56 & 0.37 & - & $<0.001$ & 0.23 \\
\hline $\mathrm{BCS}$ & 2.79 & 2.52 & 2.66 & 0.09 & 0.11 & 0.06 & - & $<0.001$ & 0.75 \\
\hline DMI (kg/d) & 13.3 & 15.2 & 15.6 & 1.01 & 0.18 & 0.06 & - & $<0.001$ & 0.78 \\
\hline DMI $(\%$ of $\mathrm{BW})$ & 1.88 & 2.24 & 2.31 & 0.18 & 0.12 & 0.04 & - & $<0.001$ & 0.50 \\
\hline Energy balance (Mcal/d) & -7.6 & -8.9 & -9.5 & 1.71 & 0.69 & 0.43 & - & $<0.001$ & 0.11 \\
\hline
\end{tabular}

${ }^{1} \mathrm{CON}=$ control; $\mathrm{MS}=\mathrm{CON}+\mathrm{MS}(0.19 \%$ of DMI $) ; \mathrm{SM}=\mathrm{CON}+\mathrm{SM}(0.07 \%$ of DMI $)$.

${ }^{2}$ Greatest SEM.

${ }^{3}$ Contrast statement of CON versus $\mathrm{MS}+\mathrm{SM}$.

${ }^{4}$ Parity (Par) effect was used in the model, depending on significance.

${ }^{5}$ Interaction of diet $\times$ time.

${ }^{6}$ Prepartum parameters were analyzed from $-21 \mathrm{~d}$ to calving.

ables for which it was significant $(P<0.05)$. Health and twinning data were analyzed with PROC FREQ of SAS, and interpreted using Fisher's exact test probabilities. Statistical differences were declared significant at $P \leq 0.05$ and tendencies at $P \leq 0.15$.

\section{RESULTS}

\section{Ingredient and Nutrient Composition of Diets}

The ingredient compositions of the diets are presented in Table 2. The nutrient composition (Table 3) was determined by analyzing each individual feed ingredient for its chemical composition and then entering the feed analysis results into the NRC (2001) model.

\section{Prepartal DMI, BW, and BCS}

An interaction $(P=0.009)$ of diet by time $(\mathbf{D} \times \mathbf{T})$ was observed for prepartal BCS (Table 4; Figure 1C); however, this could be more associated with transient differences between cows than a direct dietary effect $(P$ $=0.90)$. In fact, prepartal BW, BCS, DMI (Figure 1E), DMI as percentage of BW (Figure 1G), and prepartal EB (Figure 2A and 2C) were not affected overall by dietary treatments (Table 4). Analysis of MS + SM versus CON indicated a tendency $(P=0.12)$ for lower prepartal BW for cows fed MS + SM; however, this effect was primarily due to a lower $(P=0.03) \mathrm{BW}$ during the last week prepartum for Met-supplemented cows in comparison to CON (Figure 1A). Prepartal BW and EB were the only variables for which parity did not explain some of the variation.

\section{Postpartal DMI, BW, and BCS}

Main effects and interactions for postpartal BW, BCS, DMI, DMI as percentage of BW, and postpartal EB are presented in Table 4. In Met-supplemented cows, tendencies for postpartal BCS $(P=0.11)$, DMI $(P=0.18)$, and DMI as percentage of BW $(P=0.12)$ were reflected via the contrast $\mathrm{MS}+\mathrm{SM}$ versus $\mathrm{CON}$ in lower BCS $(P=0.06)$, greater DMI $(P=0.06)$, and greater DMI as percentage of $\mathrm{BW}(P=0.04)$. A noticeable lower BCS was observed for MS and SM from calving to $3 \mathrm{wk}$ postpartum (Figure 1D). An increase in DMI $(\mathrm{kg} / \mathrm{d}$ and as \% of BW) for MS + SM versus CON was evident from 7 to $21 \mathrm{~d}$ postpartum (Figure $1 \mathrm{~F}$ and $1 \mathrm{H})$. There was an interaction $(P=0.11)$ of $\mathrm{D} \times \mathrm{T}$ for $\mathrm{EB}$ postpartum, which can be explained by the differences in DMI and milk production among them. Although a pronounced $(P=0.06)$ decrease in $\mathrm{EB}$ of $4.8 \mathrm{Mcal} / \mathrm{d}$ (Figure 2B) was observed within 1 wk postpartum for $\mathrm{MS}+\mathrm{SM}$ versus $\mathrm{CON}$ cows, $\mathrm{EB}$ as percentage of requirements was only $12.7 \%$ lower (Figure 2D) for MS + SM versus CON cows and did not differ $(P=0.82)$. Most of this effect was associated with a numerical deficit of $5.6 \mathrm{Mcal} / \mathrm{d}(P \leq 0.14)$ for $\mathrm{SM}$ versus $\mathrm{CON}+\mathrm{MS}$ during wk 1 (Figure $2 \mathrm{~B}$ ). Although EB at 4 wk versus 1 for MS + SM was different $(P \leq 0.001)$, EB for CON cows did not differ $(P=0.39)$ throughout the 4 wk of lactation studied.

\section{Milk Production and Composition}

Main effects and $\mathrm{D} \times \mathrm{T}$ interactions for postpartal production variables, milk:DMI ratio, and ECM:DMI 
OSORIO ET AL.
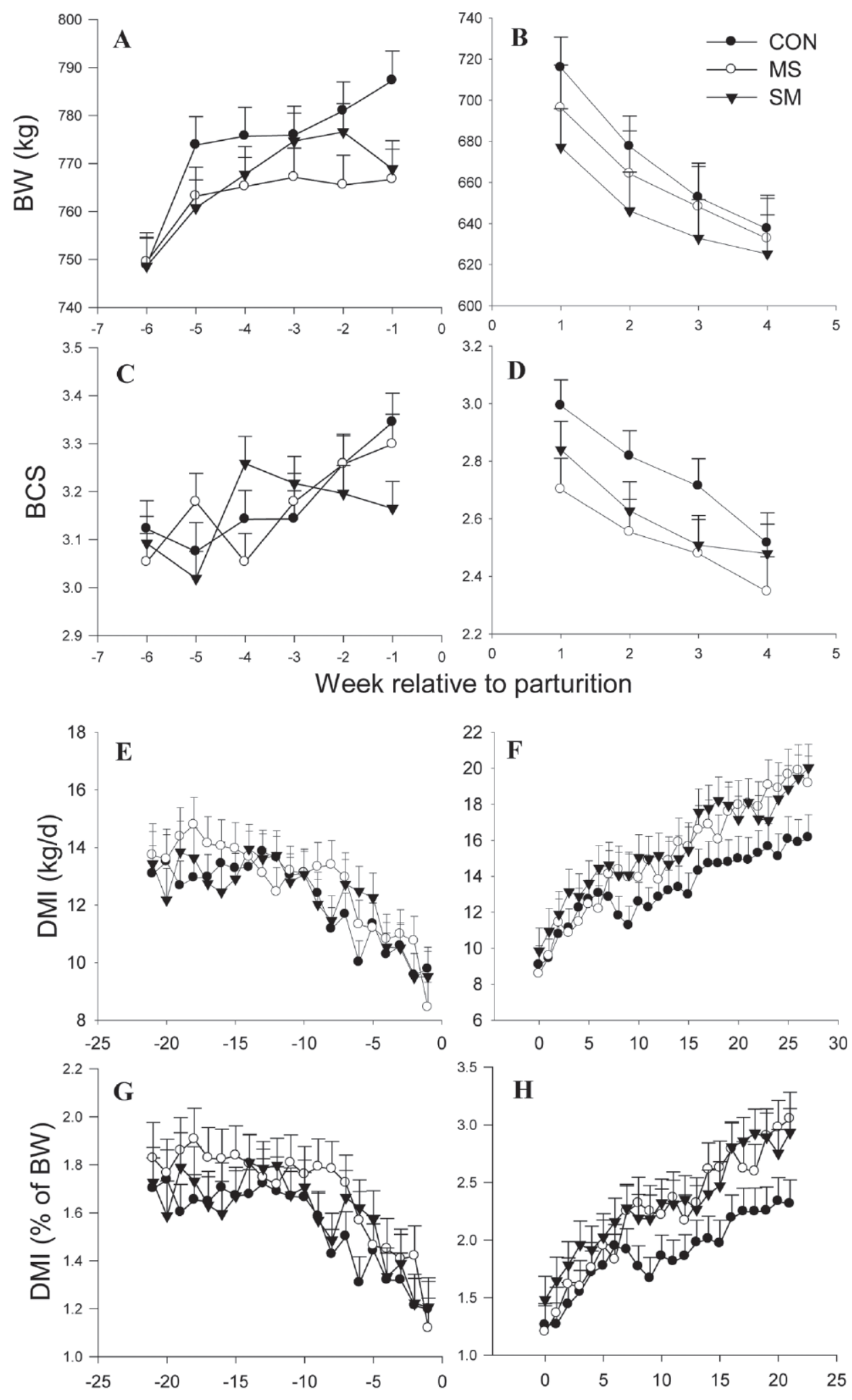

Day relative to parturition

Figure 1. Prepartal (A) and postpartal (B) BW, BCS (C, D), DMI (E, F), and DMI as percentage of BW (G, H) in cows supplemented with MetaSmart (MS; Adisseo Inc., Antony, France) or Smartamine M (SM; Adisseo Inc.) during the peripartal period. CON = control. Values are means, with standard errors represented by vertical bars. 

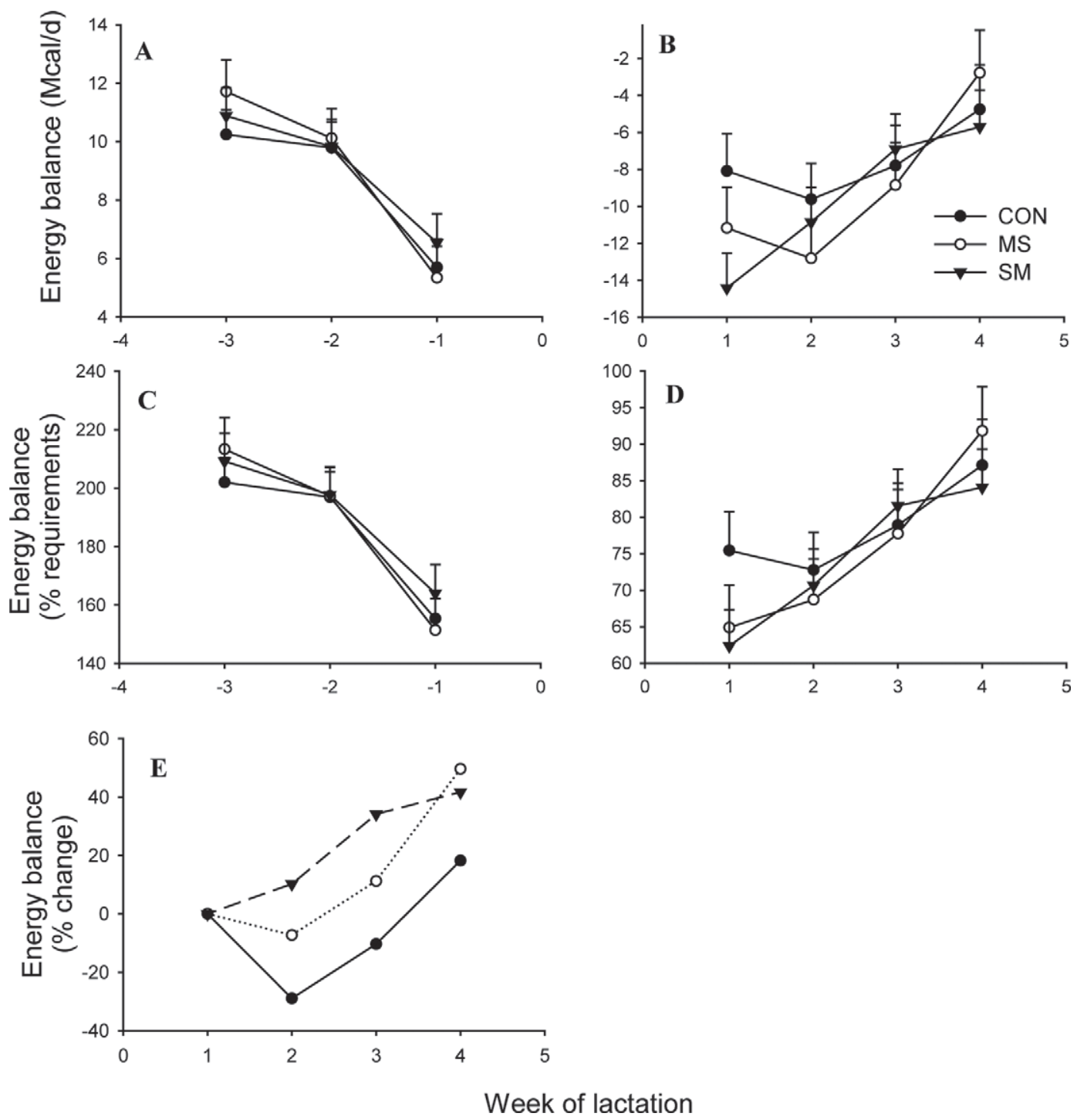

Figure 2. Prepartal energy balance (EB; Mcal/d; A), postpartal EB (Mcal/d; B), prepartal EB (\% of requirements; C), postpartal EB (\% of requirements; D), and EB (\% change with respect to 1 wk; E) in cows supplemented with MetaSmart (MS; Adisseo Inc., Antony, France) or Smartamine M (SM; Adisseo Inc.) during the peripartal period. CON = control. Values are means, with standard errors represented by vertical bars.

ratio are presented in Table 5 . An interaction $(P \leq$ 0.03 ) was observed for milk fat percentage, milk fat yield (Figure 3B), Milk:DMI ratio, and ECM:DMI ratio. A large degree of the effect observed in milk fat percentage was not only due to a greater $(P=0.006)$ fat content in SM cows during wk 1 postpartum, but also to a greater fat content in MS versus SM during wk $2(P=0.12)$ and wk $3(P=0.05$; Figure $3 \mathrm{~A})$. That effect, coupled with numerically greater milk production (Figure 3E) for SM cows during wk 1, was associated with the greater $(P<0.001)$ fat yield observed during the same time frame (Figure 3B). Similarly, MS cows tended $(P<0.13)$ to have greater fat yield during 7 to $21 \mathrm{~d}$ postpartum (Figure 3B). Although $\mathrm{D} \times \mathrm{T}$ was significant $(P=0.006)$ for ECM:DMI ratio, neither diet nor Met contrasts were significant (Figure 3G). Therefore, this effect was mainly due to the greater $(P$ $=0.07)$ Met effect during wk 1 postpartum.

Overall milk yield (Figure $3 \mathrm{E}$ ), milk protein percentage (Figure 3C) and yield (Figure 3D), milk fat yield (Figure 3B), and ECM (Figure 3F) tended $(P \leq 0.15)$ to be affected by diet. Contrast analysis, however, revealed a greater response due to feeding the Met diets than the CON diet for milk yield $(P=0.08)$, milk protein percentage $(P=0.05)$ and yield $(P=0.03)$, milk fat yield $(P=0.04)$, and ECM $(P=0.03$; Table 5$)$. 
Table 5. Effects of supplementing cows with MetaSmart (MS; Adisseo Inc., Antony, France) or Smartamine M (SM; Adisseo Inc.) during the peripartal period on production variables

\begin{tabular}{|c|c|c|c|c|c|c|c|c|c|}
\hline Parameter & \multicolumn{3}{|c|}{$\operatorname{Diet}^{1}$} & $\mathrm{SEM}^{2}$ & \multicolumn{5}{|c|}{$P$-value } \\
\hline Milk yield (kg/d) & $35.7^{\mathrm{b}}$ & $38.1^{\mathrm{ab}}$ & $40.0^{\mathrm{a}}$ & 1.6 & 0.15 & 0.08 & - & $<0.001$ & 0.86 \\
\hline Milk fat $(\%)$ & 4.27 & 4.68 & 4.09 & 0.22 & 0.59 & 0.36 & 0.05 & $<0.001$ & 0.004 \\
\hline Milk protein $(\%)$ & $3.04^{\mathrm{b}}$ & $3.26^{\mathrm{a}}$ & $3.19^{\mathrm{ab}}$ & 0.08 & 0.13 & 0.05 & - & $<0.001$ & 0.23 \\
\hline Milk fat yield $(\mathrm{kg} / \mathrm{d})$ & 1.64 & 1.84 & 1.81 & 0.08 & 0.11 & 0.04 & - & 0.04 & 0.009 \\
\hline Milk protein yield $(\mathrm{kg} / \mathrm{d})$ & $1.11^{\mathrm{a}}$ & $1.23^{\mathrm{a}}$ & $1.24^{\mathrm{a}}$ & 0.05 & 0.08 & 0.03 & - & 0.02 & 0.14 \\
\hline ECM:DMI & 3.00 & 3.39 & 3.05 & 0.22 & 0.42 & 0.40 & - & $<0.001$ & 0.006 \\
\hline
\end{tabular}

\footnotetext{
${ }^{2}$ Greatest SEM.

${ }^{3}$ Contrast statement of CON versus $\mathrm{MS}+\mathrm{SM}$.

${ }^{4}$ Parity (Par) effect was used in the model, depending on significance.

${ }^{5}$ Interaction of diet $\times$ time.
}

${ }^{\mathrm{a}, \mathrm{b}}$ Mean values within a row with different superscripts were significantly different $(P<0.05)$.

${ }^{1} \mathrm{CON}=$ control; $\mathrm{MS}=\mathrm{CON}+\mathrm{MS}(0.19 \%$ of $\mathrm{DMI}) ; \mathrm{SM}=\mathrm{CON}+\mathrm{SM}(0.07 \%$ of DMI $)$.

\section{Health}

Health-related problems that occurred during the experiment are summarized in Table 1. Among the 4 main health-related problems observed, ketosis was clearly associated with diet, as indicated by the tendency for fewer $(P=0.15)$ clinical cases in cows fed SM and MS than CON diets. It should be noted, however, that incidence of ketosis in 2 cows, one fed MS and the other fed SM, were confounded by retained placenta. Similarly, 2 other cows, one fed the CON diet and the other SM, were diagnosed with ketosis and displaced abomasum after calving. The least-affected $(P=1.00)$ health-related problem was displaced abomasum.

\section{Blood and Liver Metabolites}

The main effects of parity, diet, time, and their interactions on blood metabolites, insulin, GH, IGF1, leptin, PMNL phagocytosis, and liver tissue concentration of total lipid and TAG are presented in Table 6 . The only significant $\mathrm{D} \times \mathrm{T}$ effect was observed for NEFA $(P<$ 0.001 ), which increased substantially after calving and to a greater extent in cows fed MS on d 7 postpartum (Figure 4D). Although diet did not significantly affect any of the blood metabolites and hormones or liver tissue concentration of lipid and TAG, there were strong tendencies observed for NEFA $(P=0.12)$, GH $(P=$ $0.07)$, PMNL phagocytosis $(P=0.07)$, and liver TAG $(P=0.15)$, where Met-supplemented cows had greater $(P<0.07)$ GH $(7.51$ vs. 5.03$)$ and PMNL phagocytosis (50.4 vs. $38.5 \%$ ). Unlike GH and phagocytosis, NEFA and liver TAG concentrations were greater with MS and lower with SM compared with the CON diet (Table 6). Unlike ApoB-100, all other blood and liver parameters had a time effect, with concentrations changing over time (i.e. insulin, glucose, TAG, and VLDL decreased between at least $-17 \mathrm{~d}$ through $14 \mathrm{~d}$ postpartum; Figures 4 and 5). However, the concentration of VLDL increased to values observed prepartum on d 21 (Figure $5)$.

The parity effect was significant for $\mathrm{GH}(P=0.03)$, IGF1 $(P=0.04)$, total liver lipid $(P=0.023)$, and TAG $(P<0.001)$ concentration. As observed with blood data, the concentration of total lipid and TAG in liver changed over time due to marked increases between $\mathrm{d}$ -10 and 7 relative to calving (Figure 6). Despite the numerically greater concentration of total lipid on d 21 in cows fed the CON diet, no statistical difference was observed in concentrations of lipid and TAG between d 7 and 21.

\section{DISCUSSION}

\section{Ingredient, Nutrient Composition, and NRC Evaluation of Diets}

The mean chemical compositions of feed ingredients throughout the experiment were used to evaluate prepartal and postpartal diets through the NRC (2001) model. Unlike prepartum, postpartal MP balance was negative across dietary treatments (Table 3 ). The Metsupplemented diets (MS + SM) provided an average of $28 \mathrm{~g} / \mathrm{d}$ more MP during the close-up period than the CON diet. However, during the postpartal period, the Met-supplemented cows had a more negative MP balance (an average of $43 \mathrm{~g} / \mathrm{d}$ more) than CON cows. This was due, in part, to a greater $(321.5 \mathrm{~g} / \mathrm{d}) \mathrm{MP}$ requirement in $\mathrm{MS}+\mathrm{SM}$ versus $\mathrm{CON}$ diets in order to sustain a greater yield of milk (Table 5) during the same period.

The importance of adequate RUP supply during the transition period was further confirmed by a 15 -fold 

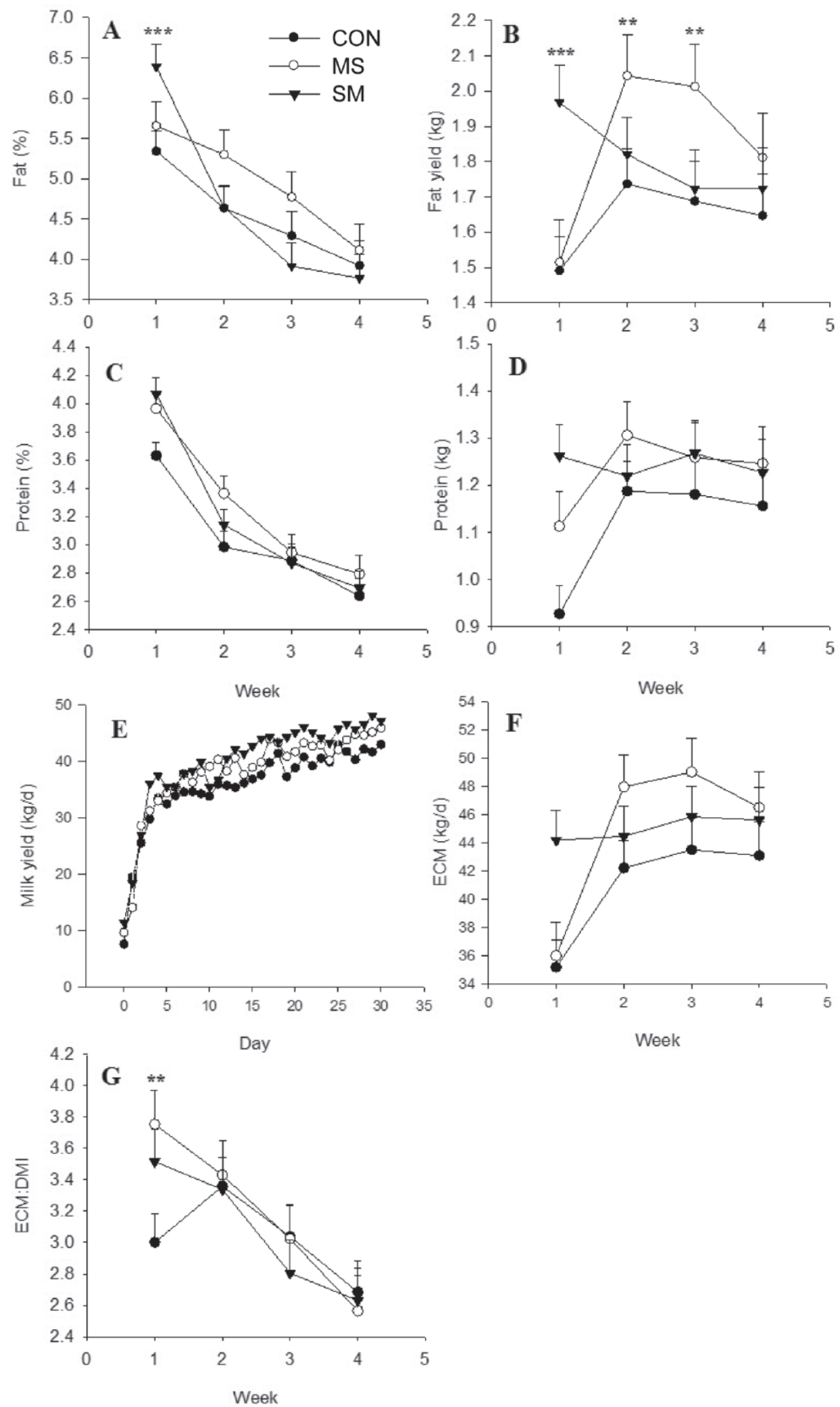

Figure 3. Milk fat percentage (A), milk fat yield (B), milk protein percentage (C), milk protein yield (D), milk yield until 30 DIM (E), ECM (F), and ECM:DMI ratio (G) in cows supplemented with MetaSmart (MS; Adisseo Inc., Antony, France) or Smartamine M (SM; Adisseo Inc.) during the peripartal period. Mean separation between diets $(P<0.05)$ were evaluated via contrasts: control $(\mathrm{CON})$ versus MS $+\mathrm{SM}(*)$, CON versus MS $(* *)$, and CON versus SM $(* * *)$. Values are means, with standard errors represented by vertical bars. 
Table 6. Effects of supplementing cows with MetaSmart (MS; Adisseo Inc., Antony, France) or Smartamine M (SM; Adisseo Inc.) during the peripartal period on blood metabolites, liver composition, and phagocytosis

\begin{tabular}{|c|c|c|c|c|c|c|c|c|c|}
\hline Parameter $^{1}$ & \multicolumn{3}{|c|}{ Treatment $^{2}$} & $\mathrm{SEM}^{3}$ & \multicolumn{5}{|c|}{$P$-value } \\
\hline NEFA (mEq/L) & 0.432 & 0.494 & 0.420 & 0.029 & 0.12 & 0.43 & - & $<0.001$ & $<0.001$ \\
\hline BHBA $(\mathrm{mmol} / \mathrm{L})$ & 0.687 & 0.697 & 0.645 & 0.057 & 0.80 & 0.82 & - & $<0.001$ & 0.33 \\
\hline $\mathrm{TAG}(\mathrm{mg} / \mathrm{dL})$ & 300.9 & 327.2 & 300.1 & 23.8 & 0.65 & 0.66 & - & $<0.001$ & 0.65 \\
\hline Insulin $(\mu \mathrm{g} / \mathrm{L})$ & 0.43 & 0.50 & 0.45 & 0.07 & 0.79 & 0.65 & - & $<0.001$ & 0.68 \\
\hline IGF1 (ng/mL) & 58.9 & 52.0 & 57.3 & 4.9 & 0.59 & 0.47 & 0.04 & $<0.001$ & 0.97 \\
\hline Leptin $(\mathrm{ng} / \mathrm{mL})$ & 5.42 & 4.36 & 4.40 & 1.24 & 0.78 & 0.49 & - & $<0.001$ & 0.12 \\
\hline VLDL $(\mu \mathrm{g} / \mu \mathrm{L})$ & 0.43 & 0.45 & 0.47 & 0.05 & 0.86 & 0.65 & - & $<0.001$ & 0.57 \\
\hline ApoB-100 (ng/mL) & 17.4 & 23.2 & 20.6 & 2.1 & 0.16 & 0.14 & - & 0.97 & 0.75 \\
\hline Phagocytosis $^{7}(\%)$ & 38.5 & 55.1 & 45.8 & 5.6 & 0.07 & 0.07 & - & - & - \\
\hline \multicolumn{10}{|l|}{ Liver (\% wet wt) } \\
\hline Total lipid & 10.55 & 9.53 & 8.66 & 1.09 & 0.39 & 0.24 & 0.023 & $<0.001$ & 0.17 \\
\hline
\end{tabular}

${ }^{1} \mathrm{TAG}=$ triacylglycerol; $\mathrm{GH}=$ growth hormone; VLDL $=$ very low density lipoproteins; ApoB-100 = apolipoprotein B-100.

${ }^{2} \mathrm{CON}=$ control; $\mathrm{MS}=\mathrm{CON}+\mathrm{MS}(0.19 \%$ of $\mathrm{DMI}) ; \mathrm{SM}=\mathrm{CON}+\mathrm{SM}(0.07 \%$ of $\mathrm{DMI})$.

${ }^{3}$ Greatest SEM of all treatments.

${ }^{4}$ Contrast statement of CON versus MS + SM.

${ }^{5}$ Parity (Par) effect was used in the model, depending on significance.

${ }^{6}$ Interaction of diet $\times$ time.

${ }^{7}$ Whole-blood leukocyte phagocytosis at 21 DIM.

increase in required RUP, regardless of treatment, from the close-up to postpartal period (Table 3). The Metsupplemented diets provided ca. 0.34 percentage units more Met in MP, which was enough to achieve an assumed more desirable Lys:Met ratio of 2.93 compared with 3.4 for MS + SM and CON diets. Concentrations of $\mathrm{NE}_{\mathrm{L}}, \mathrm{CP}, \mathrm{NDF}$, and $\mathrm{ADF}$ throughout the experiment did not differ greatly between dietary treatments. Overall, postpartal MP balance in Met-supplemented cows was lower ( -153 vs. $-617 \mathrm{~g} / \mathrm{d}$ ) in our study compared with levels reported by Ordway et al. (2009). The differences between studies could have been associated with the level of Lys and Met (as \% of MP; i.e., 0.85 and 0.16 percentage units greater in Ordway et al. (2009) than in the present study. That effect could be attributed to supplying 0.35 and $0.06 \%$ of MS and SM DM from $\mathrm{d}-21$ to calving and increase this rate to 0.54 and $0.10 \%$ of MS and SM from calving to d 140 (Ordway et al., 2009). It is likely that these differences in MP balance between studies were due to greater inclusion rates of Met supplements and length of the experimental period. During the close-up period, cows on the MS and SM diets received similar amounts of MP-lysine and $7 \mathrm{~g}$ more MP-Met than the CON cows. After calving, Met-supplemented cows received an extra ca. $15 \mathrm{~g}$ of MP-Lys and ca. $11 \mathrm{~g}$ of MP-Met (Table 3). Similar to our results, Chen et al. (2011) achieved an estimated increase of 0.37 percentage units of Met in MP over controls with Met supplementation of $0.17 \%$ of DM in the form of MS and $0.06 \%$ of DM in the form of SM.

\section{Effects on DMI, BW, and BCS}

Although a significant interaction of $\mathrm{D} \times \mathrm{T}$ was observed for BCS prepartum, this result was not associated with main effects of $\operatorname{diet}(P=0.90)$ or Met supplements $(P=0.72)$; rather, the marked changes in time plus the effect of between-cow variation appeared to explain this interaction. Our results are in agreement with previous research (Socha et al., 2005; Ordway et al., 2009) where providing Met supplements prepartum did not affect DMI, BW, or BCS.

Methionine supplementation after calving was associated with an overall increase in DMI (Table 4), along with an even more pronounced effect on DMI and DMI as percentage of BW after $7 \mathrm{~d}$ postpartum and throughout d 30 (Figure $3 \mathrm{~F}$ and $3 \mathrm{H}$ ). In this regard, previous work with MS and SM supplementation has yielded mixed results. For instance, Ordway et al. (2009) observed an increase in postpartum DMI when supplementing MS while SM did not differ from controls. Another study (Chen et al., 2011) found no effect of MS supplementation during a 12-wk period with cows at $>88$ DIM $(0.17 \%$ of DM) on DMI. In contrast, Socha et al. (2005) reported a tendency $(P \leq 0.15)$ for a decrease in DMI postpartum when supplementing 15 $\mathrm{g}$ of SM/d to a basal diet, possibly producing an imbal- 

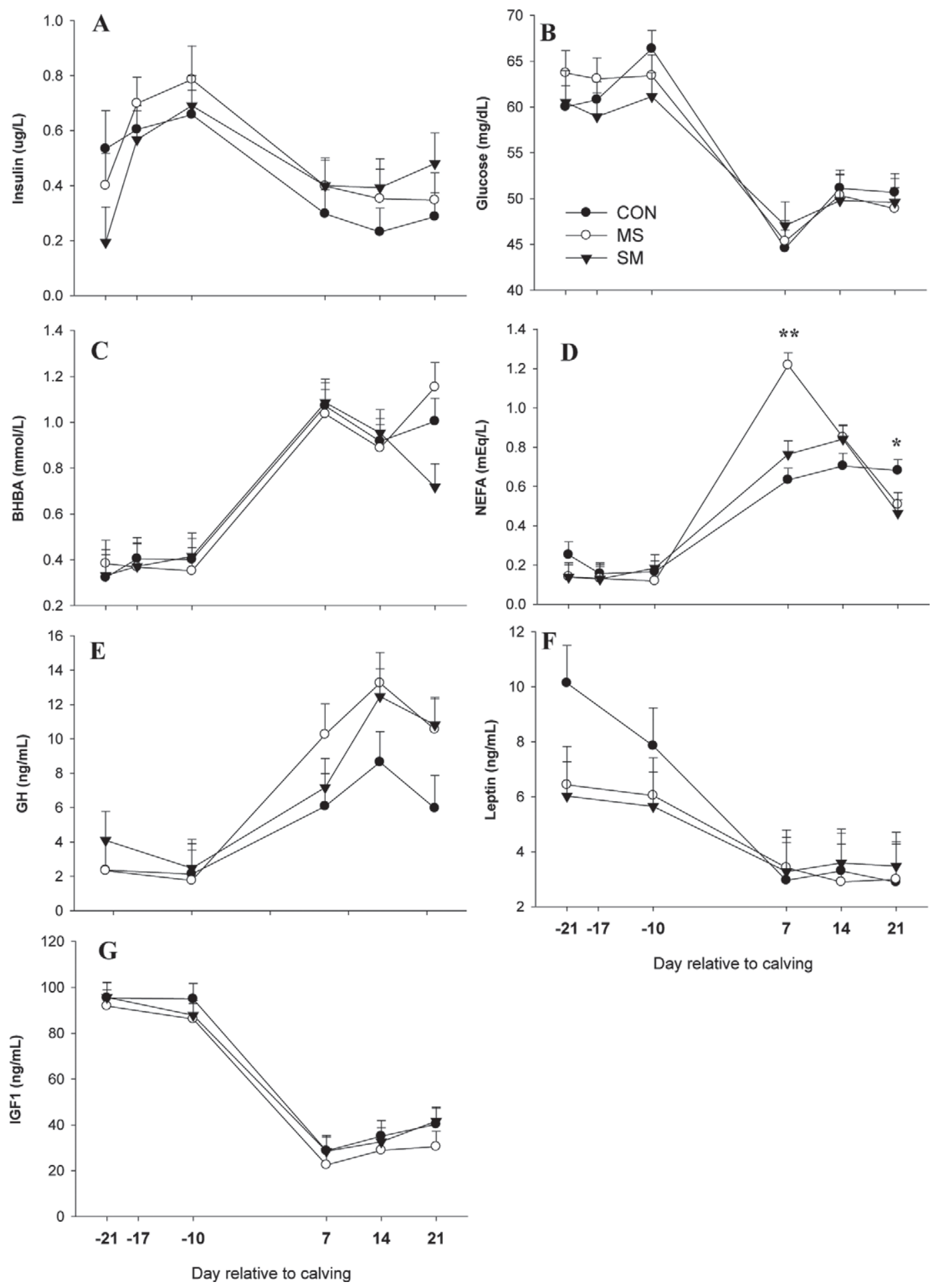

Figure 4. Effects of supplemental MetaSmart (MS; Adisseo Inc., Antony, France) or Smartamine M (SM; Adisseo Inc.) on insulin (A), glucose (B), BHBA (C), NEFA (D), growth hormone (GH; E), leptin (F), and IGF1 (G) in dairy cows during the transition period. Mean separation between diets $(P<0.05)$ were evaluated via contrasts: control $(\mathrm{CON})$ versus MS + SM $\left(^{*}\right)$, CON versus MS (**), and CON versus SM (***). Values are means, with standard errors represented by vertical bars.

ance in the Lys:Met ratio, particularly before calving (2.7:1) but also after calving (3.22:1; i.e., too much Met before calving and not enough after calving).
The inconsistent results reported to date might have been related to differences in level of Met supplementation, length of feeding, and stage of lactation (i.e. the 

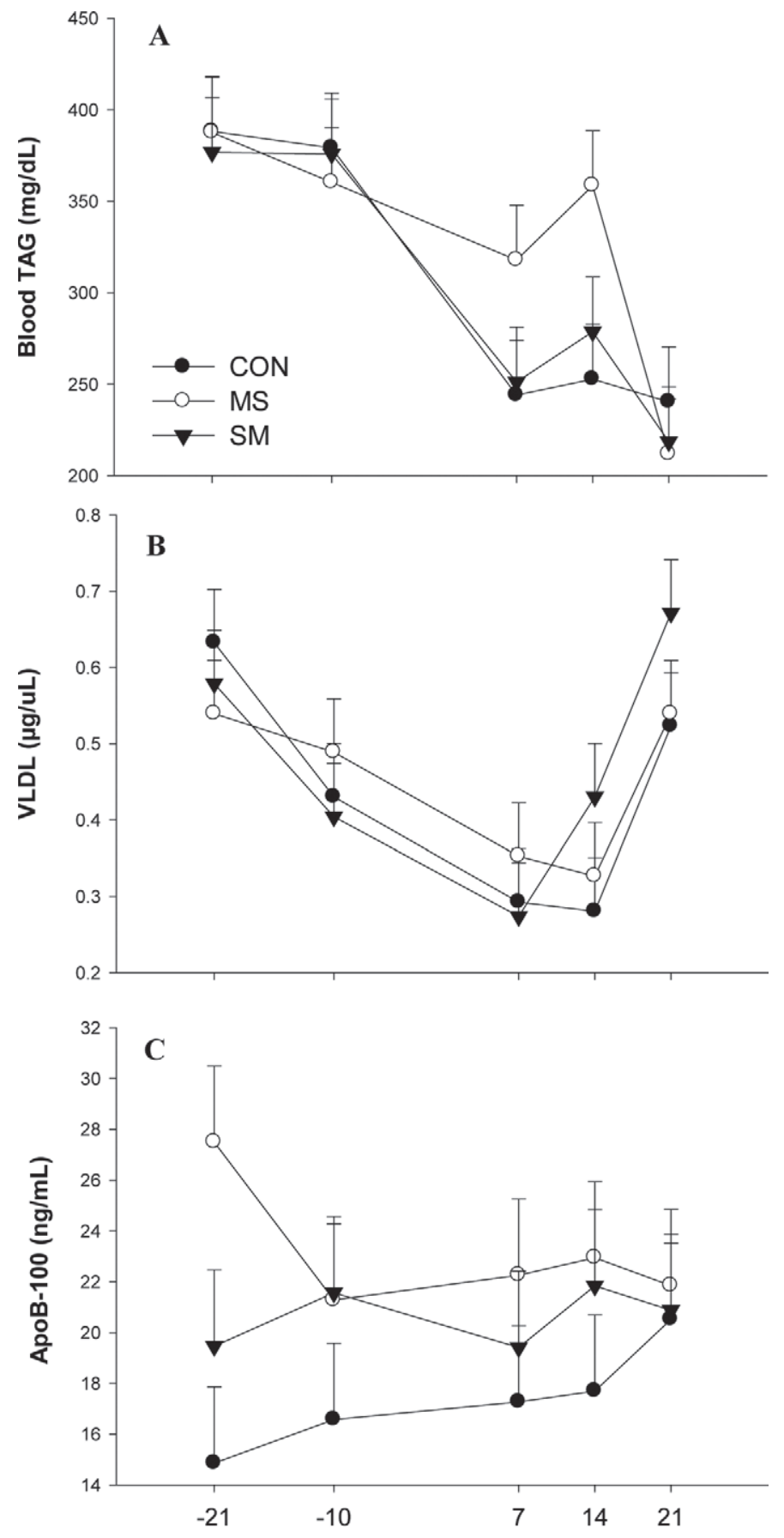

Day relative to parturition

Figure 5. Effects of supplemental MetaSmart (MS; Adisseo Inc., Antony, France) or Smartamine M (SM; Adisseo Inc.) on blood triacylglycerol (TAG; A), very low density lipoproteins (VLDL; B), and apolipoprotein B-100 (ApoB-100; C) in dairy cows during the transition period. $\mathrm{CON}=$ control. Values are means, with standard errors represented by vertical bars.

greatest responses to optimal Lys and Met nutrition occur during the early stages of lactation when the need for absorbed AA, relative to absorbed energy, is the
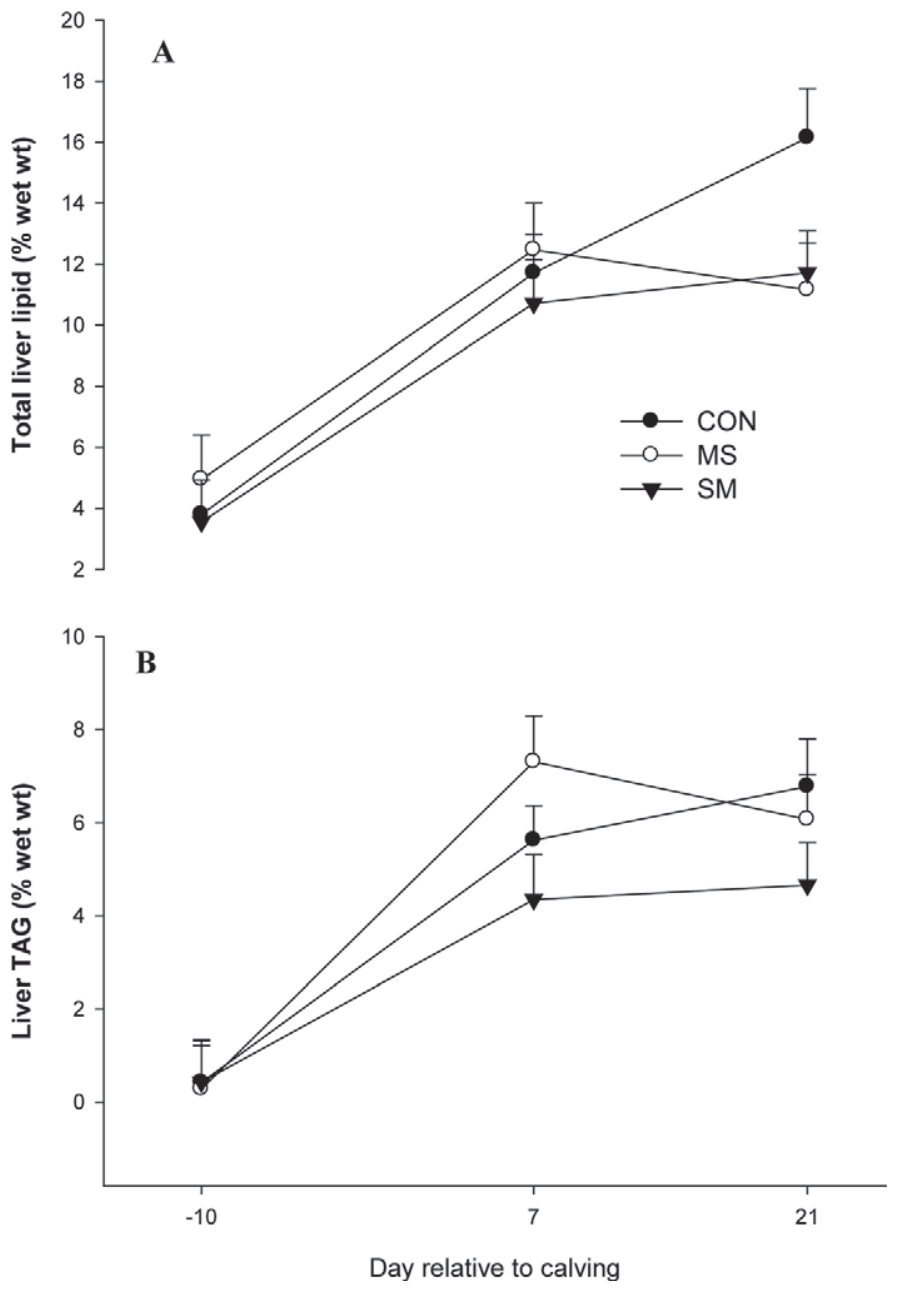

Figure 6. Effects of supplemental MetaSmart (MS; Adisseo Inc., Antony, France) or Smartamine M (SM; Adisseo Inc.) on liver composition in terms of total lipids (A) and triacylglycerol (TAG; B) in dairy cows during the transition period. Values are means, with standard errors represented by vertical bars.

highest; Socha et al., 2005). Nevertheless, our results underscore the benefit of achieving an optimal Lys:Met ratio via MS or SM during the peripartal period on enhancing voluntary feed intake during this critical physiological stage of the lactation cycle. Furthermore, it is unlikely that the intake response was solely due to supplemental Met postpartum (i.e. there might have been carryover effects of supplemental Met during the close-up period).

\section{Milk Production and Composition}

The strong tendency $(P=0.08)$ for an effect of supplemental Met on milk yield underscores the importance of optimal Met to fine-tune the profile of EAA in MP available to the early lactation cow. In fact, greater responses in milk yield to postpartum supplementation 
of SM or MS have been reported previously (St-Pierre and Sylvester, 2005). Although D $\times \mathrm{T}$ interactions were observed for milk fat percentage and milk fat yield, this was primarily associated with Met supplementation $(P \leq 0.08)$ effects because at least one Met treatment behaved differently than the other. The latter is further supported in Figure 3B, where SM improved milk fat yield during wk 1, whereas MS had the effect during wk 2 and 3. Similar to our findings, others (Chen et al., 2011) have observed an increase in milk fat percentage or milk fat yield when supplementing cows with Met and especially MS. Milk protein percentage and yield was greatly affected by Met supplementation, increasing by ca. 0.18 percentage units and $0.12 \mathrm{~kg} / \mathrm{d}$, respectively, over the CON diet. This effect has been consistently reported throughout the literature, underscoring that milk protein is affected in direct proportion to adequacy of Met in MP (NRC, 2001).

\section{Feed Intake and Apparent Efficiency}

The interaction observed for the ECM:DMI ratio could be explained mainly by an increase for MS (3.75) and SM (3.52) compared with CON cows $(3.0, P=$ 0.07 ) during wk 1 postpartum (Figure $3 \mathrm{G}$ ). These results are in agreement with those of Socha et al. (2005) and Chen et al. (2011), where an increase in ECM:DMI ratio was observed when supplementing basal diets with rumen-protected Met or rumen-protected Met and Lys. Although EB had a $\mathrm{D} \times \mathrm{T}$ interaction $(P=0.11)$, this result was not associated with a significant main effect of Met. However, evaluation of Figure 2B and 2D indicates that cows receiving MS or SM experienced a greater demand for nutrients, especially during $1 \mathrm{wk}$, which was noticeable across milk yield, milk fat yield, and ECM (Figures 3E, 3B, and 3F, respectively).

Although EB in cows fed MS + SM compared with the CON diet was lower during wk 1, the EB in CON cows did not improve at wk 4 wk compared with wk 1 , which was opposite to the response observed in cows fed MS or SM. When evaluating data from Figure 2B and the EB as percentage change with respect to wk 1 (Figure 2F), we observed that EB in MS and SM increased by $>40 \%$ at wk 4 compared with wk 1 , whereas CON cows remained below $20 \%$ of EB at wk 1. This response was consistent with both the observed $4 \mathrm{~kg} / \mathrm{d}$ increase in ECM for cows supplemented with MS + SM (Table 5) and the increase in DMI (Figure 1H).

Socha et al. (2005) and Ordway et al. (2009) reported mean values of EB between -4.15 and $-2.15 \mathrm{Mcal} / \mathrm{d}$ between the period of calving to 105 and $140 \mathrm{~d}$ postpartum. However, it is likely that differences between those studies and ours are mostly due to experimental design [i.e. starting supplementation during the close-up pe- riod ( -14 vs. $-21 \mathrm{~d})$ and also the length of supplementation postpartum]. Interestingly, Ordway et al. (2009) reported an improvement in EB when supplementing MS, while SM did not alter EB over that of the CON treatment. That response could have been associated with a greater ( 0.54 vs. $0.17 \%$ of $\mathrm{DM})$ rate of inclusion of MS in the diet compared with our experiment.

\section{Blood and Liver Tissue Metabolites As They Relate to Health}

Ketosis is a common disease during starvation or negative EB episodes, when the large uptake of adipose tissue-derived long-chain FA by the liver results in incomplete oxidation to ketone bodies (Bauchart et al., 1998). Other studies reported an increase in the occurrence of ketosis when feeding moderate-energy diets similar to ours during the dry period (Van den Top et al., 1996; Dann et al., 2006; Janovick et al., 2011). Thus, the tendency for lower incidence of clinical ketosis due to inclusion of SM and MS during the peripartal period suggests that supplemental Met might have influenced lipid metabolism in the liver.

Any lipotropic agent such as Met or choline could help to clear lipid accumulation from the liver (Durand et al., 1992), at least in part, by stimulating hepatic VLDL formation and export (Bauchart et al., 1998). Such a response consequently might lead to a reduction in liver TAG accumulation and of ketone body production (Waterman and Schultz, 1972; Bauchart et al., 1998). The lack of change in liver TAG when SM and MS were fed was not entirely surprising, as similar responses were observed previously in peripartal cows fed a different Met analog (2-hydroxy-4-methylthiobutanoic acid, Alimet; Novus International, St. Charles, MO; Piepenbrink et al., 2004). In addition, a recent study with peripartal cows fed rumen-protected choline during the transition period did not show differences in NEFA and BHBA concentrations despite lower liver TAG concentrations (Zom et al., 2011).

Although speculative, the pattern of NEFA and blood TAG observed with MS between the prepartum period and $\mathrm{d} 7$ and 14 could be taken as an indication that despite the numerically greater liver TAG concentration, the ability of liver to secrete TAG was not compromised. The actual mechanism behind such response is not readily apparent from our data; however, it might be related to ApoB-100 synthesis, as we observed a numerically greater concentration postpartum in cows fed MS relative to CON. Overall, the concentrations of liver tissue TAG on d 7 and 21 in response to MS and SM are within the range $(4-5 \%$, wet wt basis) reported recently in cows supplemented with rumen-protected choline (Zom et al., 2011). More importantly, however, 
our data underscored the fact that liver TAG in cows did not affect DMI and the ability of the cows fed SM or MS to produce more milk.

\section{Blood Neutrophil-Killing Capacity}

Human lymphocytes seem to have an absolute requirement for Met to proliferate (Hall et al., 1986), which may partly be responsible for the positive effect of supplemental Met on the immune function of monogastrics (Nauss et al., 1982; Tsiagbe et al., 1987) and likely ruminants (Soder and Holden, 1999), as well. For instance, mid-lactation cows supplemented with $30 \mathrm{~g} / \mathrm{d}$ of rumen-protected Met (Mepron 85) compared with 0 or $15 \mathrm{~g} / \mathrm{d}$ had greater $\mathrm{T}$ lymphocyte proliferation in vitro in response to various mitogens (Soder and Holden, 1999). The greater blood neutrophil-killing capacity that we observed postpartum with SM and SM provides additional evidence of an important role for Met in the immune response during the transition period. Whether the greater phagocytosis was a result of more cells or a more pronounced oxidative burst response (or both) remains to be established.

\section{Endocrine Responses}

The temporal changes observed for the concentration of insulin, GH, IGF1, and leptin agree with the expected patterns for these hormones around parturition (Radcliff et al., 2003; Rabelo et al., 2005; Janovick et al., 2011). To our knowledge, endocrine effects to supplemental rumen-protected Met in peripartal cows have not been reported. However, studies performed with post-peak lactating dairy cows have reported greater insulin concentration in response to SM at doses greater than the ones used in the present study, which would be expected because amino acids are insulinotropic (Blum et al., 1999; Misciattelli et al., 2003).

The tendency for greater GH with Met supplementation, namely MS, was unexpected because in a previous study with lactating dairy cows, supplemental SM did not alter GH or IGF1 concentration (Misciattelli et al., 2003). It is well established that in nonlactating ruminants, low-protein diets reduce circulating IGF1 concentrations and the responsiveness of the liver to GH (Breier et al., 1988; Wynn et al., 1991). Work with sheep hepatocytes in vitro demonstrated that Met availability is essential for IGF1 mRNA and protein synthesis, and that limitations in Met dampen the ability of GH to stimulate IGF1 synthesis (Stubbs et al., 2002). The reduction of GH receptor expression in the liver of peripartal cows is one factor that accounts for the low mRNA expression and blood circulation of IGF1, particularly after calving (Radcliff et al., 2003).
Whether supplemental Met is functionally related to the GH/IGF1 axis during the peripartal period remains to be determined.

\section{CONCLUSIONS}

The findings of this study reveal that supplementation with MS or SM when Lys is adequate to achieve an approximately 2.9:1 Lys:Met ratio can improve milk production, at least in part, by increasing voluntary DMI and perhaps by optimizing the use of body lipid reserves. Such responses were more evident during the first week postpartum when SM- or MS-supplemented cows had an increased ECM:DMI ratio while in more negative $\mathrm{EB}$ with respect to $\mathrm{CON}$ cows, and regaining similar EB as CON cows by wk 2. As originally hypothesized, the overall milk protein and milk fat concentration was positively affected by Met supplementation. To the authors' knowledge, this is the first study where a simultaneous improvement in postpartal DMI, milk production-related traits, and better leukocyte-killing capacity have been observed while supplementing basal diets with MS or SM, further supporting the benefit of using those products for fine-tuning of EAA in MP.

\section{ACKNOWLEDGMENTS}

The authors gratefully acknowledge Adisseo (Commentry, France) for partial financial support of this research. The authors thank Travis Michels and Mike Katterhenry of the University of Illinois Dairy Research Unit (Urbana) staff for help with animal management.

\section{REFERENCES}

Armentano, L. E., S. J. Bertics, and G. A. Ducharme. 1997. Response of lactating cows to methionine or methionine plus lysine added to high protein diets based on alfalfa and heated soybeans. J. Dairy Sci. 80:1194-1199.

Auboiron, S., D. Durand, D. Bauchart, J.-C. Robert, and M. J. Chapman. 1994. Lipoprotein metabolism in the preruminant calf: Effect of a high fat diet supplemented with L-methionine. J. Dairy Sci. 77:1870-1881.

Auboiron, S., D. Durand, J. C. Robert, M. J. Chapman, and D. Bauchart. 1995. Effects of dietary fat and L-methionine on the hepatic metabolism of very low density lipoproteins in the preruminant calf, Bos spp. Reprod. Nutr. Dev. 35:167-178.

Ballou, M. A. 2012. Immune responses of Holstein and Jersey calves during the preweaning and immediate postweaned periods when fed varying planes of milk replacer. J. Dairy Sci. 95:7319-7330.

Bauchart, D., D. Durand, D. Gruffat, and Y. Chilliard. 1998. Mechanism of liver steatosis in early lactation cows: Effects of hepatoprotector agents. Pages 27-37 in Proc. Cornell Nutr. Conf. Feed Manuf. Cornell University, Ithaca, NY.

Blum, J. W., R. M. Bruckmaier, and F. Jans. 1999. Rumen-protected methionine fed to dairy cows: Bioavailability and effects on plasma amino acid pattern and plasma metabolite and insulin concentrations. J. Dairy Sci. 82:1991-1998.

Breier, B. H., P. D. Gluckman, and J. J. Bass. 1988. Influence of nutritional status and oestradiol- $17 \beta$ on plasma growth hormone, 
insulin-like growth factors-I and -II and the response to exogenous growth hormone in young steers. J. Endocrinol. 118:243-250.

Chen, Y., Y. Yang, M. L. Miller, D. Shen, H. G. Shertzer, K. F. Stringer, B. Wang, S. N. Schneider, D. W. Nebert, and T. P. Dalton. 2007. Hepatocyte-specific Gclc deletion leads to rapid onset of steatosis with mitochondrial injury and liver failure. Hepatology 45:1118-1128.

Chen, Z. H., G. A. Broderick, N. D. Luchini, B. K. Sloan, and E. Devillard. 2011. Effect of feeding different sources of rumen-protected methionine on milk production and N-utilization in lactating dairy cows. J. Dairy Sci. 94:1978-1988.

Dann, H. M., N. B. Litherland, J. P. Underwood, M. Bionaz, A. D'Angelo, J. W. McFadden, and J. K. Drackley. 2006. Diets during far-off and close-up dry periods affect periparturient metabolism and lactation in multiparous cows. J. Dairy Sci. 89:3563-3577.

Durand, D., Y. Chilliard, and D. Bauchart. 1992. Effect of lysine and methionine on in vivo hepatic secretion of VLDL in the high yielding dairy cow. J. Dairy Sci. 75(Suppl. 1):279. (Abstr.)

Graugnard, D. E., K. M. Moyes, E. Trevisi, M. J. Khan, D. Keisler, J. K. Drackley, G. Bertoni, and J. J. Loor. 2013. Liver lipid content and inflammometabolic indices in peripartal dairy cows are altered in response to prepartal energy intake and postpartal intramammary inflammatory challenge. J. Dairy Sci. 96:918-935.

Graulet, B., C. Richard, and J. C. Robert. 2005. Methionine availability in plasma of dairy cows supplemented with methionine hydroxy analog isopropyl ester. J. Dairy Sci. 88:3640-3649.

Greenfield, R. B., M. J. Cecava, T. R. Johnson, and S. S. Donkin. 2000. Impact of dietary protein amount and rumen undegradability on intake, peripartum liver triglyceride, plasma metabolites, and milk production in transition dairy cattle. J. Dairy Sci. 83:703-710.

Hall, C. A., J. A. Begley, and R. C. Chu. 1986. Methionine dependency of cultured human lymphocytes. Proc. Soc. Exp. Biol. Med. 182:215-220.

Hutjens, M. F. 2010. Benchmarking your feed efficiency, feed costs, and income over feed cost. Pages 3-10 in Proc. Western Canadian Dairy Seminar, Red Deer, Alberta, Canada. University of Alberta, Edmonton, Alberta, Canada.

Huyler, M. T., R. L. Kincaid, and D. F. Dostal. 1999. Metabolic and yield responses of multiparous Holstein cows to prepartum rumenundegradable protein. J. Dairy Sci. 82:527-536.

Ingvartsen, K. L., and J. B. Andersen. 2000. Integration of metabolism and intake regulation: A review focusing on periparturient animals. J. Dairy Sci. 83:1573-1597.

Janovick, N. A., Y. R. Boisclair, and J. K. Drackley. 2011. Prepartum dietary energy intake affects metabolism and health during the periparturient period in primiparous and multiparous Holstein cows. J. Dairy Sci. 94:1385-1400.

Johnson-VanWieringen, L. M., J. H. Harrison, D. Davidson, M. L. Swift, M. A. G. von Keyserlingk, M. Vazquez-Anon, D. Wright, and W. Chalupa. 2007. Effects of rumen-undegradable protein sources and supplemental 2-hydroxy-4-(methylthio)-butanoic acid and lysine- $\mathrm{HCl}$ on lactation performance in dairy cows. J. Dairy Sci. 90:5176-5188.

Martinov, M. V., V. M. Vitvitsky, R. Banerjee, and F. I. Ataullakhanov. 2010. The logic of the hepatic methionine metabolic cycle. Biochim. Biophys. Acta 1804:89-96.

Misciattelli, L., V. F. Kristensen, M. Vestergaard, M. R. Weisbjerg, K Sejrsen, and T. Hvelplund. 2003. Milk production, nutrient utilization, and endocrine responses to increased postruminal lysine and methionine supply in dairy cows. J. Dairy Sci. 86:275-286.

Nauss, K. M., A. M. Connor, A. Kavanaugh, and P. M. Newberne. 1982. Alterations in immune function in rats caused by dietary lipotrope deficiency: Effect of age. J. Nutr. 112:2333-2341.

NRC. 2001. Nutrient Requirements of Dairy Cattle. 7th ed. Natl. Acad. Press, Washington, DC.

Ordway, R. S., S. E. Boucher, N. L. Whitehouse, C. G. Schwab, and B. K. Sloan. 2009. Effects of providing two forms of supplemental methionine to periparturient Holstein dairy cows on feed intake and lactational performance. J. Dairy Sci. 92:5154-5166.
Phillips, G. J., T. L. Citron, J. S. Sage, K. A. Cummins, M. J. Cecava, and J. P. McNamara. 2003. Adaptations in body muscle and fat in transition dairy cattle fed differing amounts of protein and methionine hydroxy analog. J. Dairy Sci. 86:3634-3647.

Piepenbrink, M. S., A. L. Marr, M. R. Waldron, W. R. Butler, T. R. Overton, M. Vazquez-Anon, and M. D. Holt. 2004. Feeding 2-hydroxy-4-(methylthio)-butanoic acid to periparturient dairy cows improves milk production but not hepatic metabolism. J. Dairy Sci. 87:1071-1084.

Rabelo, E., R. L. Rezende, S. J. Bertics, and R. R. Grummer. 2005. Effects of pre- and postfresh transition diets varying in dietary energy density on metabolic status of periparturient dairy cows. J. Dairy Sci. 88:4375-4383.

Radcliff, R. P., B. L. McCormack, B. A. Crooker, and M. C. Lucy. 2003. Plasma hormones and expression of growth hormone receptor and insulin-like growth factor-I mRNA in hepatic tissue of periparturient dairy cows. J. Dairy Sci. 86:3920-3926.

Robert, J.-C., C. Richard, and B. Bouza. 2001. Influence of monomer and dimmer forms of isopropyl ester of HMB on the supply of metabolizable methionine to the blood of ruminants. J. Dairy Sci. 84(Suppl. 1):281. (Abstr.)

Rulquin, H., and L. Delaby. 1997. Effects of the energy balance of dairy cows on lactational responses to rumen-protected methionine. J. Dairy Sci. 80:2513-2522.

Rulquin, H., B. Graulet, L. Delaby, and J. C. Robert. 2006. Effect of different forms of methionine on lactational performance of dairy cows. J. Dairy Sci. 89:4387-4394.

Schwab, C. G. 2007. Protected proteins and amino acids for ruminants. Pages 115-141 in Biotechnology in Animal Feeds and Animal Feeding. Wiley-VCH Verlag GmbH, Weinheim, Germany.

Socha, M. T., D. E. Putnam, B. D. Garthwaite, N. L. Whitehouse, N. A. Kierstead, C. G. Schwab, G. A. Ducharme, and J. C. Robert. 2005. Improving intestinal amino acid supply of pre- and postpartum dairy cows with rumen-protected methionine and lysine. J. Dairy Sci. 88:1113-1126.

Soder, K. J., and L. A. Holden. 1999. Lymphocyte proliferation response of lactating dairy cows fed varying concentrations of rumen-protected methionine. J. Dairy Sci. 82:1935-1942.

St-Pierre, N. R., and J. T. Sylvester. 2005. Effects of 2-hydroxy4-(methylthio) butanoic acid (HMB) and its isopropyl ester on milk production and composition by Holstein cows. J. Dairy Sci. 88:2487-2497.

Stubbs, A. K., N. M. Wheelhouse, M. A. Lomax, and D. G. Hazlerigg. 2002. Nutrient-hormone interaction in the ovine liver: Methionine supply selectively modulates growth hormone-induced IGF-I gene expression. J. Endocrinol. 174:335-341.

Tsiagbe, V. K., M. E. Cook, A. E. Harper, and M. L. Sunde. 1987. Enhanced immune responses in broiler chicks fed methionine-supplemented diets. Poult. Sci. 66:1147-1154.

Van den Top, A. M., M. J. Geelen, T. Wensing, G. H. Wentink, A. T. Van 't Klooster, and A. C. Beynen. 1996. Higher postpartum hepatic triacylglycerol concentrations in dairy cows with free rather than restricted access to feed during the dry period are associated with lower activities of hepatic glycerolphosphate acyltransferase. J. Nutr. 126:76-85.

Waterman, R., and L. H. Schultz. 1972. Methionine hydroxy analog treatment of bovine ketosis: Effects on circulating metabolites and interrelationships. J. Dairy Sci. 55:1513-1516.

Wynn, P. C., M. C. Stuart, A. L. Wallace, A. C. Kirby, and E. F. Annison. 1991. Influence of nutritional status on growth hormonedependent circulating somatomedin-C activity in mature sheep. J. Endocrinol. 130:313-320.

Zom, R. L. G., J. van Baal, R. M. A. Goselink, J. A. Bakker, M. J. de Veth, and A. M. van Vuuren. 2011. Effect of rumen-protected choline on performance, blood metabolites, and hepatic triacylglycerols of periparturient dairy cattle. J. Dairy Sci. 94:4016-4027. 